\title{
Multiple functions for Pax6 in mouse eye and nasal development
}

\author{
Jane C. Quinn, ${ }^{1}$ John D. West, ${ }^{1}$ and Robert E. Hill ${ }^{2,3}$ \\ ${ }^{1}$ Department of Obstetrics and Gynecology, University of Edinburgh, Centre for Reproductive Biology, Edinburgh, EH3 \\ 9EW, UK ${ }^{2}$ MRC Human Genetics Unit, Western General Hospital, Edinburgh EH4 2XU, UK
}

\begin{abstract}
Mouse embryos, homozygous for the small eye (Sey) mutation die soon after birth with severe facial abnormalities that result from the failure of the eyes and nasal cavities to develop. Mutations in the Pax6 gene are responsible for the Sey phenotype. As a general disruption of eye and nasal development occurs in the homozygous Sey embryos, it is unclear, from the mutant phenotype alone, which tissues require functional Pax6. To examine the roles for Pax6 in eye and nasal development we produced chimeric mouse embryos composed of wild-type and Sey mutant cells. In these embryos we found that mutant cells were excluded from both the lens and nasal epithelium. Both of these tissues were smaller, and in some cases absent, in chimeras with high proportions of mutant cells. The morphology of the optic cup was also severely affected in these chimeras; mutant cells were excluded from the retinal pigmented epithelium and did not intermix with wild-type cells in other regions. The evidence shows that Pax6 has distinct roles in the nasal epithelium and the principal tissue components of the embryonic eye, acting directly and cell autonomously in the optic cup and lens. We suggest that Pax6 may promote cell surface changes in the optic cup and control the fate of the ectoderm from which the lens and nasal epithelia are derived.
\end{abstract}

[Key Words: Pax6; Sey; small eye; mouse; chimera; eye; lens; nose; nasal epithelium]

Received November 1, 1995; accepted in revised version January 18, 1996.

Mutations in the Pax6 gene result in a range of abnormalities. In man these include the autosomal dominant conditions of aniridia (Ton et al. 1991; Jordan et al. 1992; Hanson et al. 1993) and Peter's anomaly (Hanson et al. 1994), which both affect the anterior chambers of the eye. In both mouse (Hill et al. 1991) and rat (Matsuo et al. 19931, Pax6 lesions are responsible for the semidominant phenotype small eye (Sey). The heterozygous phenotype of Sey in mouse shows related manifestations seen in human conditions (Jordan et al. 1992; Hanson et al. 1994) with additional associated micropthalmia. More severe phenotypes are seen in homozygous condition in rats (Matsuo et al. 1993) and mice (Hogan et al. 1986, 1988) and in a compound heterozygous human (Glaser et al. 1994). In mice, homozygous Sey/Sey is lethal at birth, leads to disruption of eye development and lack of nasal cavities in the embryo (Hogan et al. 1986, 1988), and lack of olfactory bulbs and abnormal cortical plate formation in the brain (Schmahl et al. 1993).

Pax 6 and other members of the Pax gene family have the characteristics of being important regulatory elements whose roles are central to normal development (for a recent review, see Stuart et al. 1994). We have exploited the small eye phenotype to define more clearly the developmental roles of $P a x 6$, focusing primarily on the overt eye and nasal abnormalities. Eye development

\footnotetext{
${ }^{3}$ Corresponding author.
}

proceeds from two principal tissue components: the neural ectoderm, which buds from the forebrain to form the optic vesicle, and the surface ectoderm, which forms the lens. The optic vesicle invaginates, producing the optic cup with an inner layer, which forms the neural retina, and an outer layer, which forms the retinal pigmented epithelium (RPE). The lens placode is a morphological intermediate of lens formation, characterized as an area of thickened columnar epithelium, which comes into contact with the optic vesicle. Continued eye development is dependent on the mutual interaction and invagination of these two tissues (Coulombre 1965; Smelser 1965; Saha et al. 1989; Grainger 1992). In the Sey/Sey homozygous mouse and rat the initial contact between the optic vesicle and head ectoderm occurs; however, there is no evidence for the formation of the lens primordium. The optic vesicle subsequently loses contact with the surface and degenerates (Hogan et al. 1986; Fujiwara et al. 1994; Grindley et al. 1995).

Like the lens, the nasal cavities form from the invagination of ectodermal placodes. Hogan et al. (1986) have considered this similarity and suggested that the eye and nasal phenotype of Sey/Sey mice may result from defective placode formation. In support of this suggestion, Pax6 is initially expressed broadly in the head ectoderm and subsequently becomes localized in the placodes of these two tissues (Li et al. 1994; Grindley et al. 1995). However, in the eye, Pax6 is also expressed in the optic vesicle and later in both the inner and outer layers of the 
optic cup, and in the distal optic stalk (Walther and Gruss 1991; Grindley et al. 1995). Defects in any of these expressing components of the eye could interfere with essential tissue-tissue interactions and lead to a phenotype resembling that of Sey/Sey.

To investigate the relevance of the expression pattern of Pax6 to the Sey/Sey phenotype we have produced fetal mouse aggregation chimeras composed of a mixture of wild-type and small eye mutant cells. Chimeras of four genotype combinations were produced and distinguished retrospectively by PCR analysis. The distribution of mutant Sey cells was determined by the inclusion of three genetic markers. These studies have enabled us to investigate the developmental potential of the cells that express Pax 6 before 12.5 days gestation (E12.5) in different tissues of the developing eye and nose. We have also investigated the suggestion that the Sey mutation may have similar effects in the lens and nasal epithelium.

\section{Results}

\section{Production of chimeras}

Production of Sey/Sey $\leftrightarrow+1+$ chimeras is hampered by lethality of the Sey/Sey mice. This means that Sey/Sey embryos must be produced by $($ Sey $/+\times$ Sey $/+\mid$ matings and distinguished from other genotypes retrospectively. To facilitate identification of different genotypic classes of chimeras, we produced chimeras with compound heterozygous $\left(\mathrm{Sey}^{\mathrm{Neu}} / \mathrm{Sey}\right)$ embryos, rather than homozygous (Sey/Sey) embryos (Fig. 1). Both the Sey and Sey Neu small eye alleles contain point mutations that result in loss of functional PAX6 protein (Hill et al. 1991) and are distinguishable by a PCR assay (Fig. 2). The same phenotypic abnormalities are seen in homozygous Sey/Sey, $\mathrm{Sey}^{\mathrm{Neu}} / \mathrm{Sey}^{\mathrm{Neu}}$ (Hill et al. 1991; Schmahl et al. 1993) and $\mathrm{Sey}^{\mathrm{Neu}} / \mathrm{Sey}$ compound heterozygous embryos (J.C. Quinn, unpubl.). To distinguish between different classes of chimeras, we used embryos from crosses between heterozygous $\mathrm{Sey}^{\mathrm{Neu} /}+$ females and heterozygous Sey $/+$ males, both of which are pigmented $(C / C)$ and homozygous for the glucose phosphate isomerase Gpi1 ${ }^{b}$ allele. The Sey/ + males were also homozygous $(\mathrm{Tg} / \mathrm{Tg})$ for the reiterated $\mathrm{TgN}(\mathrm{Hbb}-\mathrm{b} 1) 83 \mathrm{Clo}, \beta$-globin transgene (Lo 1986; Lo et al. 1987; West et al. 1995). Consequently all of the embryos produced by the Sey ${ }^{\mathrm{Neu}} /+\times \mathrm{Sey} /+$ cross were $\mathrm{Tg} /$ - heterozygotes. These embryos were aggregated to albino BALB/c strain embryos $\left(G p i 1^{a}, c /\right.$ $G p i 1^{a} \mathrm{c}$ ) to produce chimeric fetuses, which were analyzed at E12.5 days (Fig. 1). Four groups of chimeras were distinguished by PCR analysis of Pax6 DNA: Sey ${ }^{\mathrm{Neu}}$ / Sey $\leftrightarrow+1+, \quad$ Sey Neu $/+\leftrightarrow+/+, \quad$ Sey $/+\leftrightarrow+/+, \quad$ and $+/+\leftrightarrow+/+$. The contribution of the $\mid \mathrm{Sey}^{\mathrm{Neu}} /+\times$ Sey $/$ $+\mid$ embryo was estimated in different tissues to test the developmental potential of Sey ${ }^{\mathrm{Neu}} / \mathrm{Sey}$ compound heterozygous cells in the Sey ${ }^{\mathrm{Neu}} / \mathrm{Sey} \leftrightarrow+/+$ fetal chimeras. This estimate was based on a combination of GPI electrophoresis, eye pigmentation, and DNA in situ hybridization to the $\beta$-globin transgene.

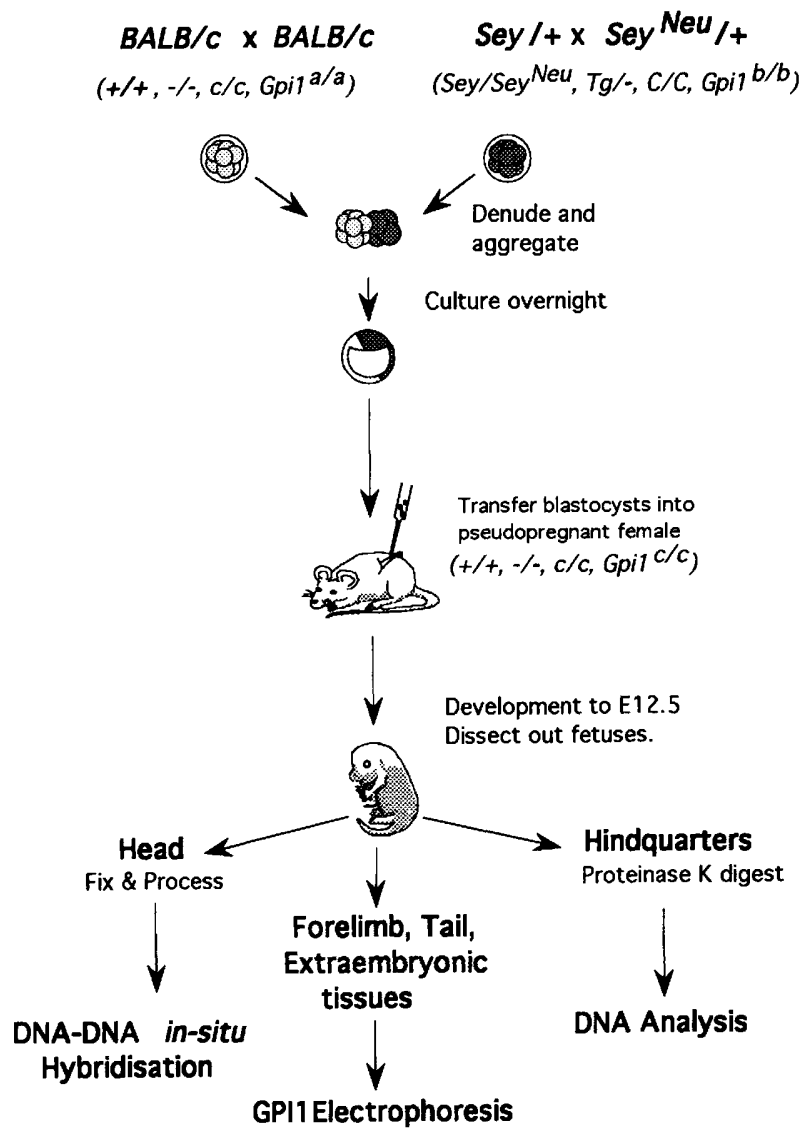

Figure 1. Schematic representation of the experimental design for investigation of the role of $\mathrm{Pax} 6$ in eye and nasal development. Two small eye mutant strains were intercrossed to produce eight-cell stage embryos that were all genetically pigmented $(C / C)$, homozygous Gpi1 ${ }^{b} / G p i 1^{b}$, hemizygous for the $\beta$-globin transgene $(\mathrm{Tg} /-)$ but differed at the small eye locus $\left(\mathrm{Sey}^{\mathrm{Neu}} / \mathrm{Sey}, \mathrm{Sey}^{\mathrm{Neu}} /+, \mathrm{Sey} /+\right.$ or $+/+$ ). These were aggregated to inbred BALB/c embryos (albino, $c / c$, homozygous Gpi1 ${ }^{a}$ ) Gpi $1^{a}$, nontransgenic, $-/-$, and wild-type for small eye, $+/+1$ to produce aggregation chimeras. At E12.5, Sey ${ }^{\mathrm{Neu}} / \mathrm{Sey} \leftrightarrow+1+$ and the three control groups $\left(\right.$ Sey $^{\text {Neu }} /+\leftrightarrow+/+$, Sey $/+\leftrightarrow+/+$ and $+1+\leftrightarrow+1+$ ) of chimeras were distinguished by DNA analysis. The contribution from the $\left(\mathrm{Sey} /+\times \mathrm{Sey}^{\mathrm{Neu}} /+\right)$ embryo was quantified by DNA in situ hybridization to various tissues in the head and GPI1 electrophoresis of the tail, forelimb, amnion, whole yolk sac, and placenta.

Thirty-seven fetal chimeras were produced $(7 \mathrm{Sey} N e u$ / Sey $\leftrightarrow+/+, 7 \mathrm{Sey}^{\mathrm{Neu}} /+\leftrightarrow+/+, 7 \mathrm{Sey} /+\leftrightarrow+/+$, and 16 $+1+\leftrightarrow+1+1$. Although the presence of GPIIA and GPI1B confirmed that these were all chimeric, eye pigment was not observed in any of the $\mathrm{Sey}^{\mathrm{Neu}} / \mathrm{Sey} \leftrightarrow+1+$ chimeras (discussed below). Absence of eye pigment was not attributable to retarded development, as statistical analysis revealed no significant differences, among the four groups, in median developmental stage (Kruskal Wallis test of hindlimb morphology|, mean conceptus weight, fetus weight, placental weight or crown-rump length (analysis of variance). The chimeras in the other groups had variegated eyes, as expected. 


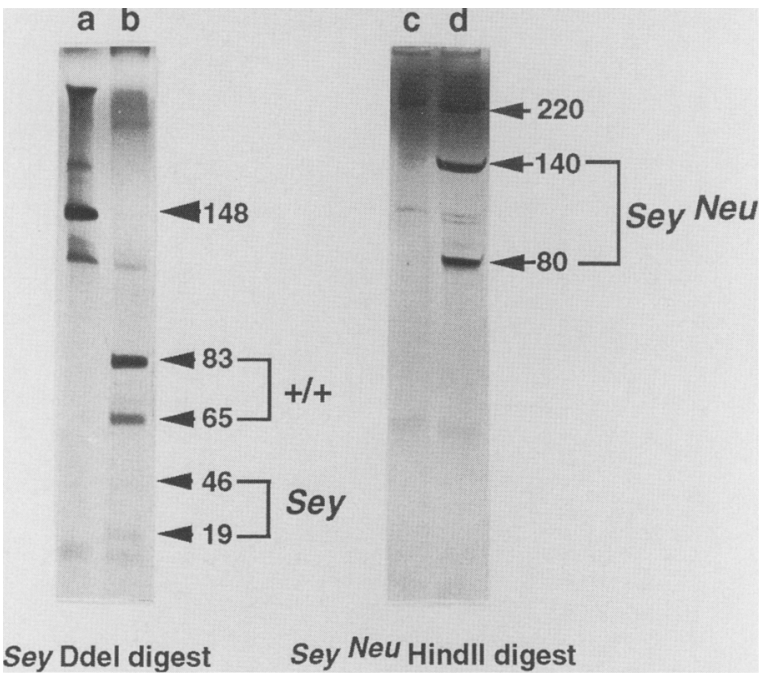

Figure 2. Analysis of genomic DNA from chimeric fetuses allows identification of Sey genotypes. Both the Sey and Sey ${ }^{\mathrm{Neu}}$ alleles have single-base-pair changes within the Pax6 gene that give rise to novel DdeI and HindII restriction enzyme sites, respectively. Digestion of a 148-bp PCR product with $D$ deI gives fragment sizes of 83 and $65 \mathrm{bp}$ in the wild type with additional 46- and 19-bp fragments in the Sey mutant (lane $a$ is undigested; lane $b$ is digested). After digestion, the Sey ${ }^{\mathrm{Neu}}$ mutation gives rise to 140 - and 80 -bp fragments from a $220-b p$ PCR product (lane $c$ is undigested; lane $d$ is digested).

Histological sections revealed several striking morphological abnormalities in $\mathrm{Sey}^{\mathrm{Neu}} / \mathrm{Sey} \leftrightarrow+/+$ chimeras but none in the other groups of chimeras. Three (JC17, IC48, and JC50) of the seven Sey ${ }^{\mathrm{Neu}} / \mathrm{Sey} \leftrightarrow+/+$ chimeras had abnormal bulging eyes with overgrown abnormal optic cup tissue but no lenses (Fig. 3). The lenses were absent from both eyes of chimeras JC17 (Fig. 3D) and JC50 and from the right eye of chimaera JC48 (Fig. 3A). In two other chimeras (JC56 and the left eye of JC61) the lenses were present but markedly smaller than normal. This was also the case in the left eye of JC48 (Fig. 3A,C).

\section{Thresholds for proper lens and nasal epithelium development}

Initial analysis of the chimeras was based on an estimate of the overall contribution of $\left(\mathrm{Sey}^{\mathrm{Neu}} /+\times \mathrm{Sey} /+\mid\right.$ cells to the fetus [mean percent GPIIB (mean \% GPIIB) in the tail and forelimb] and histology of the eye and nasal epithelium. GPI analysis showed that the contribution of the Sey ${ }^{\mathrm{Neu}} / \mathrm{Sey}$ cells to the Sey Neu/Sey $\leftrightarrow+1+$ chimeras that lacked lenses was high $180 \%$ for JC17, 76\% for JC50, and $56 \%$ for JC48, missing one lens|. The mean \% GPI1B for each of the other four Sey ${ }^{\mathrm{Neu}} / \mathrm{Sey} \leftrightarrow+1+$ chimeras was lower (range $11 \%-46 \%$; Table 1). A similar relationship was seen for the nasal epithelium.

The sizes of lenses and nasal epithelia were estimated in the Sey ${ }^{\mathrm{Neu}} / \mathrm{Sey} \leftrightarrow+1+$ chimeras and found to be inversely correlated with the \% GPI1B $\left(\mathrm{Sey}^{\mathrm{Neu}} / \mathrm{Sey}\right)$ contribution to the fetus (Fig. 4). This suggests that the sizes of the lenses and nasal epithelia are quantitatively dependent on the proportion of wild-type cells in the Sey ${ }^{\mathrm{Neu}} /$ Sey $\leftrightarrow+1+$ chimeras. In the 10 chimeras from the other three groups that were analyzed, the sizes of the lenses or nasal epithelia were not affected by the presence of $\mathrm{Sey}^{\mathrm{Neu}} /+$ or Sey/ + cells and showed no relationship with the percent fetal GPIlB. There was no reduction in lens size in Sey $/+\leftrightarrow+/+$ or $\mathrm{Sey}^{\mathrm{Neu}} /+\leftrightarrow+/+$ chimeras even though both Sey/ + and Sey $\mathrm{Neu} /+$ heterozygous adults have small eyes.

In $\mathrm{Sey}^{\mathrm{Neu}} / \mathrm{Sey} \leftrightarrow+/+$ chimeras, lens development appeared to be more sensitive than nasal epithelium development, showing a critical threshold at $\sim 50 \%-70 \%$ contribution of Sey ${ }^{N e u} / \mathrm{Sey}$ cells (Fig. 4a). Chimeras approaching this threshold formed small lenses, and beyond this threshold lenses were not formed. The threshold is likely to exert its effect in the surface ectoderm or the lens placodes and if the proportion of $\mathrm{Sey}^{\mathrm{Neu}} / \mathrm{Sey}$ cells differs between left and right lens primordia this may result in unilateral effects. Several examples of chimeras with different sized lenses are shown in Table 1. The right lens of JC61 was much larger than the left lens, and JC48 had only a lens in the left eye, as shown in Figure 3A. Presumably the proportion of $\mathrm{Sey}^{\mathrm{Neu}} / \mathrm{Sey}$ cells was just below the critical threshold in the head ectoderm that produced the lens placode in the left eye of JC48 (with a small lens) but was above this level in the right eye (no lens).

The lens and nasal epithelia sizes are both related to the chimeric composition in the Sey ${ }^{\mathrm{Neu}} / \mathrm{Sey} \leftrightarrow+/+$ chi- $^{-}$ meras, and either tissue may be absent unilaterally (Table 1). The shapes of the curves in Figure 4, a and b, appear to differ, and this suggests that the kinetics of the relationships between composition and tissue size may differ. In Figure $4 \mathrm{~b}$ there is a nearly linear relationship between the extent of nasal epithelia and the \%GPIIB $\left(\mathrm{Sey}^{\mathrm{Neu}} / \mathrm{Sey}\right)$ contribution to the fetus, whereas Figure 4a appears more sigmoidal and the size of the lens appears constant until the proportion of mutant cells reaches $\sim 40 \%$. It is clear that a critical percentage of wild-type cells is required to coordinate formation of both these tissues, below which they cannot form. Although there are too few animals to draw firm conclusions, it appears that different thresholds of normal cells are required for the production of the lens and nasal epithelium.

\section{Cellular composition of lens and nasal epithelium}

The tissue composition of 16 chimeras $13-5$ in each group) was analyzed in more detail by estimations of the percent eye pigment and the percentage of $T g /$ - cells, by DNA in situ hybridization to the $\beta$-globin transgene (Fig. 3). The quantitative results of the analysis of three widely spaced sections of each tissue are shown in Figure 5 and Table 1. For most of the tissues analyzed from the $11 \mathrm{Sey}^{\mathrm{Neu}} /+\leftrightarrow+/+$, Sey $/+\leftrightarrow+/+$ and $+/+\leftrightarrow+/+$ chimeras, the hybridization index correlated significantly with the mean percent fetal GPI1B (see Fig. 5 legend for statistical analysis). In $\mathrm{Sey}^{\mathrm{Neu}} / \mathrm{Sey} \leftrightarrow+/+$ chimeras, contributions from both parental genotypes in each 
Figure 3. (A) Low-power photograph of a transverse histological section of the head of Sey ${ }^{\mathrm{Neu}} / \mathrm{Sey} \leftrightarrow+1+$ chimera JC48, showing both eyes. The right eye has no lens, and the optic cup is overgrown. The left eye has a small lens and is shown in higher magnification in $C$. $(B)$ Histological section of the left eye of $+/+\leftrightarrow+1+$ chimera JC49, showing a high contribution of $T g /-$ cells (positive signal seen as dark spots in the nuclei after in situ hybridization) in all tissues and pigmented cells in the retinal pigmented epithelium (outer layer). (C) Histological section of the left eye of $\mathrm{Sey}^{\mathrm{Neu}} / \mathrm{Sey} \leftrightarrow+1+$ chimera JC48 shown in $A$, showing complete absence of nuclei with in situ hybridization signal (absence of $\mathrm{Sey}^{\mathrm{Neu}}$ /Sey cells) in the lens and division of the optic cup into large domains of almost entirely wild-type cells (no hybridization signal; small arrows) and almost entirely Sey ${ }^{\mathrm{Neu}} / \mathrm{Sey}$ cells (with hybridization signal; large arrows), respectively. Two boundaries between the domains of mutant and wild-type cells are indicated with open arrows. $(D)$ Histological section of the left eye of $\mathrm{Sey}^{\mathrm{Neu}} / \mathrm{Sey} \leftrightarrow+/+$ chimera $\mathrm{IC1} 7$ with a multilayered optic cup and no lens. The optic cup is divided into large domains of almost entirely wild-type cells /central region with no hybridization signal; small arrows) and almost entirely $\mathrm{Sey}^{\mathrm{Neu}} / \mathrm{Sey}$ cells /with hybridization signal; large arrows|, respectively. One boundary between the domains of mutant and wild-type cells is indicated with an open arrow. $(E)$ Histological section of the right eye of $\mathrm{Sey}^{\mathrm{Neu} /}$ Sey↔ $+1+$ chimera JC61. The lens and optic cup are more normal but both lack mutant cells (no nuclei with hybridization signal). (F) Higher magnification of part of the eye shown in E. Hybridization signal can been seen in some mesoderm cells and one cell in the hyaloid plexus but not in the

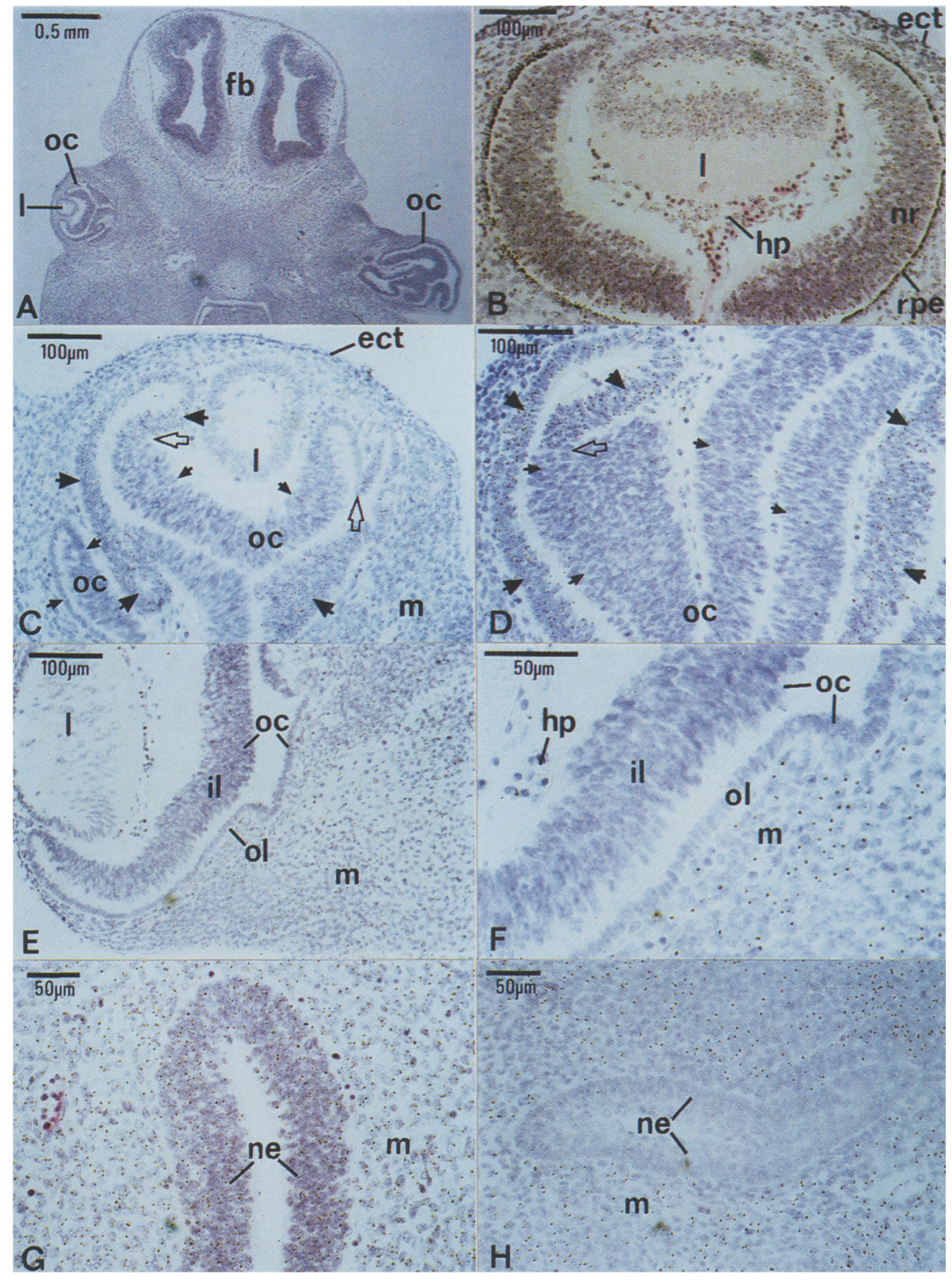
inner or outer layers of the optic cup. $|G|$

Histological section of the head of $+1+\leftrightarrow+1+$ chimera JC49 showing in situ hybridization to some cells in both the left nasal epithelium and surrounding mesoderm. $(H)$ Histological section of the head of Sey ${ }^{N e u} /$ Sey $\leftrightarrow+/+$ chimera JC61 showing in situ

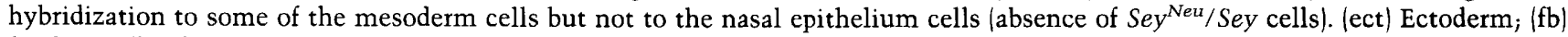
forebrain; (hp) hyaloid plexus; (il) inner layer of optic cup; (l) lens; (m) mesoderm; (ne) nasal epithelium; (nr) neural retina; (oc) optic cup; (ol) outer layer of optic cup; (rpe) retinal pigmented epithelium.

chimera were found in regions unaffected by the Sey genotype, including tail, forelimb, head mesoderm, head ectoderm, proximal optic stalk, and hindbrain (Fig. 5) plus amnion, yolk sac, and placenta (not shown). In striking contrast, however, no hybridization signals to $T g /-$ (Sey $^{\mathrm{Neu}} / \mathrm{Sey}$ ) cells were found in the lenses and nasal epithelia (where present) of the five $\mathrm{Sey}^{\mathrm{Neu}} / \mathrm{Sey} \leftrightarrow+1+$ embryos analyzed (Fig. 3C,E,H). Hybridization signals were found, however, in all three control groups, and $+/+\leftrightarrow+/+$ tissues are illustrated in Figure 3, B and G. Further analysis of every available section of Sey Neu/ Sey $\leftrightarrow+1+$ eyes (13-25 sections containing lens tissue) confirmed that mutant cells were completely absent from all of the lenses. Similarly, in the nasal epithelia, only 2-14 scattered cells were found in all available sections of the five $\mathrm{Sey}^{\mathrm{Neu}} / \mathrm{Sey} \leftrightarrow+/+$ chimeras (10-32 sections per chimera). This is consistent with the low falsepositive frequencies seen in this (data not shown) and other (Everett and West 1996) studies. We conclude that Sey ${ }^{\mathrm{Neu}} / \mathrm{Sey}$ cells are effectively excluded from the nasal epithelium as well as the lens. This exclusion shows that they cannot be rescued by neighboring wild-type cells and implies that Pax6 acts cell autonomously within prospective lens and nasal epithelium. 
Table 1. Relationships between chimera composition, eye morphology, and sizes of lens and nasal epithelia in E12.5 fetal Sey ${ }^{\mathrm{Neu}} / \mathrm{Sey} \leftrightarrow+1+$ chimeras

\begin{tabular}{|c|c|c|c|c|c|c|c|c|}
\hline \multirow[b]{2}{*}{ Chimera } & \multirow[b]{2}{*}{ Side } & \multirow{2}{*}{$\begin{array}{l}\% \text { GPIlB } \\
\text { in fetus }\end{array}$} & \multicolumn{3}{|c|}{$T g /-$ in optic cup } & \multirow{2}{*}{$\begin{array}{l}\text { Optic cup } \\
\text { dysmorphologyc }\end{array}$} & \multicolumn{2}{|c|}{$\begin{array}{l}\text { Area in section } \\
\left(\mu \mathrm{m}^{2} \times 10^{4}\right)^{\mathrm{d}}\end{array}$} \\
\hline & & & inner layer & outer layer & total & & lens & nasal epithelium \\
\hline JC63 & left & 11.0 & 0.3 & 0 & 0.2 & + & 4.5 & 14.7 \\
\hline JC63 & right & 11.0 & 0.3 & 0 & 0.2 & + & 5.7 & 15.9 \\
\hline JC35 & left & 27.5 & N.D. & N.D. & N.D. & + & 5.5 & 9.8 \\
\hline JC35 & right & 27.5 & N.D. & N.D. & N.D. & + & 4.7 & 13.5 \\
\hline JC56 & left & 42.8 & 0.3 & 38.2 & 20.5 & +++ & 3.9 & 7.4 \\
\hline JC56 & right & 42.8 & $0^{\mathrm{e}}$ & $0^{\mathrm{e}}$ & $0^{\mathrm{e}}$ & + & 5.7 & 11.0 \\
\hline JC61 & left & 46.9 & $0^{\mathrm{e}}$ & $0^{\mathrm{e}}$ & $0^{\mathrm{e}}$ & +++ & 2.1 & 1.2 \\
\hline JC61 & right & 46.9 & $0^{\mathrm{e}}$ & 19.3 & 7.3 & ++ & 6.1 & 2.5 \\
\hline JC48 & left & 59.2 & 12.0 & 33.3 & 23.4 & ++++ & 2.6 & 4.9 \\
\hline JC48 & right & 59.2 & N.A. & N.A. & 18.1 & +++++ & 0 & 2.5 \\
\hline JC50 & left & 76.8 & N.A. & N.A. & N.D. & +++++ & 0 & 0 \\
\hline JC50 & right & 76.8 & N.A. & N.A. & N.D. & +++++ & 0 & 0 \\
\hline $\mathrm{JCl} 7$ & left & 80.3 & N.A. & N.A. & 45.6 & +++++ & 0 & 2.5 \\
\hline $\mathrm{ICl} 7$ & right & 80.3 & N.A. & N.A. & 29.6 & +++++ & 0 & 0 \\
\hline
\end{tabular}

Treating each eye as a separate sample, the mean percent fetal GPIIB correlated positively with the percent $\mathrm{Tg} /-\mathrm{cells}$ in the total optic cup (Spearman's rank correlation coefficient, $\mathrm{r}_{\mathrm{s}}=0.731 ; P=0.028$ ), and the size of the lens correlated positively with the size of the nasal epithelium $\left(\mathrm{r}_{\mathrm{s}}=0.736 ; P=0.008\right)$. The degree of morphological abnormality of the optic cup correlated negatively with lens size $\left\langle\mathrm{r}_{\mathrm{s}}=-0.899 ; P=0.001\right)$ and positively with percent $\mathrm{Tg} /-$ cells in the whole optic cup $\left(\mathrm{r}_{\mathrm{s}}=0.781 ; P=0.019\right)$ and percent fetal GPI1B $\left\langle\mathrm{r}_{\mathrm{s}}=0.933 ; P=0.001\right)$. Lens size also correlated inversely with percent fetal GPI1B $\left(\mathrm{r}_{\mathrm{s}}=-0.789 ; P=0.004\right)$ but not with the percent $\mathrm{Tg} /-$ cells in the whole optic cup $\left(\mathrm{r}_{\mathrm{s}}=-0.588 ; P=0.078\right)$.

a\%GPIB is the mean \% GPI1B in the tail and one forelimb.

${ }^{\mathrm{b}} \mathrm{Tg} / \mathrm{-}$ in optic cup is the hybridization index in three widely spaced sections. Separate values are shown for the inner and outer layers of the optic cup where these layers can be clearly distinguished; otherwise the total value is shown (as plotted in Fig. 5). None of the $\mathrm{Tg} /$ - cells in the outer layer were pigmented and so they were not normal RPE cells. (N.D.) Not determined; (N.A.) not applicable. 'Optic cup dysmorphology is shown on a subjective 5-point scale: $(+\mid$ Normal morphology with double-cup comprising an outer layer of RPE and inner neural retina; $1++$ ) slightly abnormal; $(+++)$ abnormal tissue present but double-cup shaped morphology largely retained; $(++++)$ abnormal with distortion of the double-cup shape; $(+++++)$ grossly dysmorphic and multilayered.

dArea was estimated with a Chalkley grid as described in Materials and methods.

'Although no hybridization signal was seen in the three histological sections examined for the quantitative analysis, qualitative analysis of all of the available sections revealed a few $\mathrm{Tg} /-$ cells.

\section{Cellular composition of the optic cup}

Development of the optic cup was also abnormal in the $\mathrm{Sey}^{\mathrm{Neu}} / \mathrm{Sey} \leftrightarrow+1+$ chimeras but not in any of the other groups of chimeras. At the stage of development examined (E12.5) the optic cup is normally composed of an outer unicellular layer of RPE and a closely opposed thicker inner layer of prospective neural retina (Fig. 3B). The state of the optic cup in the Sey ${ }^{\mathrm{Neu}} / \mathrm{Sey} \leftrightarrow+/+$ chimeras was highly variable. Some of the gross abnormalities made it difficult to assign cells to normal tissues; therefore, in Figure 5 the optic cup is considered as a whole. The extent of the morphological abnormalities was apparently influenced by the size of the lens and the proportion of the Sey ${ }^{\mathrm{Neu}} / \mathrm{Sey}$ cells in the chimera, two parameters that are interdependent and negatively correlated (Fig. 4; Table 1). Two distinctive classes of embryonic eyes arose in the Sey ${ }^{\mathrm{Neu}} / \mathrm{Sey} \leftrightarrow+1+$ chimeras. One class includes the optic cups that are associated with lenses, all having the characteristic double layer cup shape. Morphologically, these range from optic cups that appear normal (JC63, JC35, and JC56 right eye; Table 1) to dysmorphic cups that are distorted with ectopic tissue overgrowth (JC56 left eye, JC61 and JC48 left eye;
Table 1; Fig. 3C,E). The second class of optic cup structures have no associated lenses and are highly disorganized and overgrown (JC48 right eye, JC50 and JC17; Table 1; Fig. 3A,D).

Figure 5 shows that in $\mathrm{Sey}^{\mathrm{Neu}} / \mathrm{Sey} \leftrightarrow+/+$ chimeras, the proportion of mutant cells was lower in the optic cup than in other unaffected tissues. Although the contribution was lower in the whole optic cups (mean hybridization index $=14.5$ ) than the fetal limb and tail (mean $\% \mathrm{GPIIB}=48.0$ ), the significance of this is uncertain because there was also a difference in the other groups of chimeras $(47.4 \%$ vs. $62.3 \%)$. The inner and outer layers of the optic cup were considered separately for seven $\mathrm{Sey}^{\mathrm{Neu}} / \mathrm{Sey} \leftrightarrow+1+$ eyes in Table 1. The inner layer had a lower proportion of mutant cells, which made up $<1 \%$ except for the JC48 left eye $(12 \%)$. Here, the mutant cells were specifically at the tip of the optic cup in a morphologically abnormal region (Fig. 3C). In the outer layer, the $\mathrm{Sey}^{\mathrm{Neu}} / \mathrm{Sey}$ cells contributed more significantly to three of the seven eyes $(19 \%-38 \%$ in JC61 right, JC48 left, and JC56 left; Table 1) but were not incorporated into the thin monolayer of the RPE (Fig. 3E,F). The mutant cells were usually associated with regions of the outer layer that are either abnormally thickened or situated ectopi- 
(a)

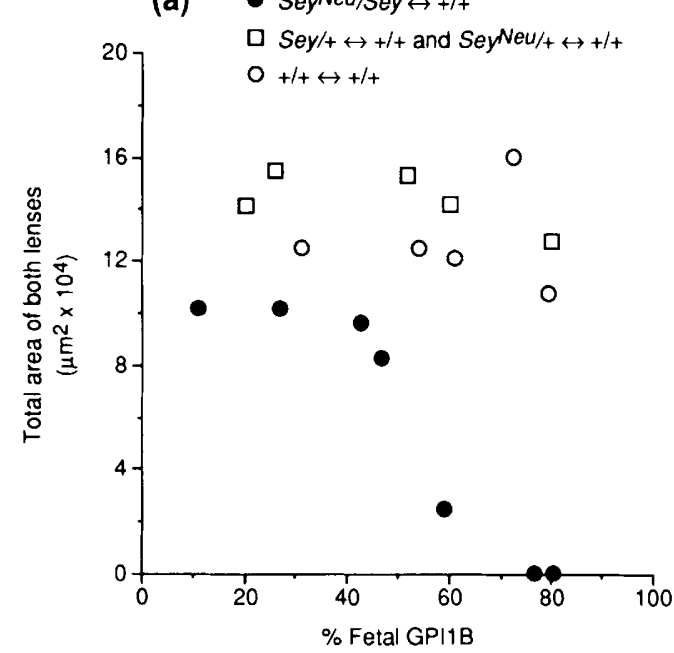

(b)

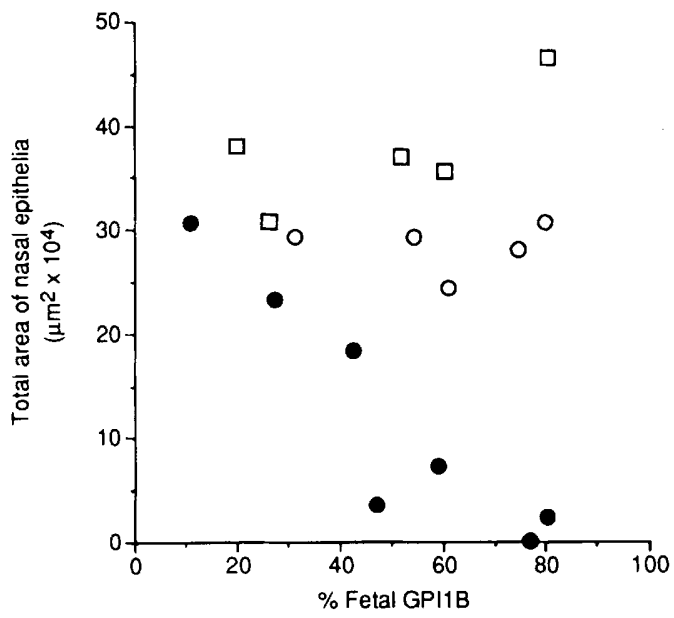

Figure 4. Relationship between the percent fetal GPIB and the estimated sizes of both lenses $(a)$ and both nasal epithelia $(b)$ for different groups of chimeras. $(a)$ The total size of both lenses showed a statistically significant negative correlation with the \% GPIlB in Sey ${ }^{\mathrm{Neu}} /$ Sey $\leftrightarrow+1+$ chimeras $\left(\mathrm{r}_{\mathrm{s}}=-0.982 ; \mathrm{P}=0.016\right)$ but not in the other groups of chimeras analyzed $\left\{\mathrm{r}_{\mathrm{s}}=-0.564 ; P=0.259\right.$ for Sey Neu $/+\leftrightarrow+1+$ plus Sey $/+\leftrightarrow+1+$ and $r_{s}=-0.359 ; P=0.473$ for $+/+\leftrightarrow+1+1$. Similarly, the total size of the nasal epithelia was also negatively correlated with the \%GPI1B in Sey ${ }^{\mathrm{Neu}} / \mathrm{Sey} \leftrightarrow+/+$ chimeras $\left(\mathrm{r}_{\mathrm{s}}=-0.929 ; P=0.023\right)$ but not in the other groups $\left(\mathrm{r}_{\mathrm{s}}=0.300\right.$; $P=0.549$ for Sey Neu $/+\leftrightarrow+/+$ plus Sey $/+\leftrightarrow+/+$ and $r_{s}=0.154 ; P=0.758$ for $+/+\leftrightarrow+/+1$. The estimated sizes of the lenses and nasal epithelia were positively correlated, both when left and right sides were pooled $\left(\mathrm{r}_{\mathrm{s}}=0.946 ; P=0.021\right)$ or when they were considered separately (Table 1).

cally. These regions were not composed exclusively of mutant cells but contained significant proportions of wild-type cells, which occurred as segregated patches and were not intermingled with the mutant cells. The optic cups that appeared normal showed little or no $\mathrm{Sey}^{\mathrm{Neu}} / \mathrm{Sey}$ contribution to either layer (Table 1; Fig. 3D). Furthermore, the inability of the Sey ${ }^{\mathrm{Neu}} / \mathrm{Sey}$ cells (the pigmented component of the chimeras) to successfully contribute to the RPE is supported by the observation that none of the eyes of the Sey ${ }^{\mathrm{Neu}} / \mathrm{Sey} \leftrightarrow+/+$ chi- $^{-}$ meras showed any detectable pigmentation.

Mutant Sey ${ }^{\mathrm{Neu}} / \mathrm{Sey}$ cells made a significant contribution to the morphologically abnormal optic cups of the second class of eyes (with no lenses) as well as the morphologically abnormal regions of optic cups in the eyes with lenses. In both cases, the mutant cells were nonrandomly distributed and not finely mixed with wildtype cells. There was a striking partitioning of the two cell types (Fig. 3D), which was not seen in the control chimeras. In the wild-type domains there were few mu$\operatorname{tant}(\mathrm{Tg} /-\mid$ cells and no detectable wild-type cells in the mutant domains. (Because not all mutant $\mathrm{Tg} /$ - cells show a hybridization signal, it is not known whether wild-type cells were completely absent from mutant domains or present at a low level). Segregation of cell types is unusual in mouse chimeras and implies that the interactions between $\mathrm{Sey}^{\mathrm{Neu}} / \mathrm{Sey}$ and $+1+$ cells are abnormal so that they either fail to mix and intermingle or actively sort themselves out into homogeneous patches. This suggests that Pax 6 expression defines early cellular properties (possibly affecting the cell surface) within the optic vesicle. The evidence that $S e y^{\mathrm{Neu}} / \mathrm{Sey}$ cells are ex- cluded from the RPE and at a selective disadvantage in other regions of the optic cup, as well as being distributed nonrandomly, implies that Pax6 has a direct, cellautonomous effect not only in the lens and nasal epithelium (see above) but also in the optic cup.

\section{Discussion}

The eye is a complex organ that develops from the interaction of two embryologically distinct ectodermal layers: the head surface ectoderm and the neural ectoderm. Analysis of Sey/Sey homozygous and phenotypically equivalent, Sey/Sey ${ }^{\mathrm{Neu}}$ compound heterozygous mutant mice shows that the development of the embryonic eye is disrupted but provides only a few clues as to the mechanism. Thus, a clear understanding of the role of the gene responsible, $P a x 6$, is difficult to surmise. To investigate the developmental potential of the Sey/ Sey ${ }^{\mathrm{Neu}}$ compound heterozygous mutant cells, we produced mouse chimeras by aggregating mutant (Sey) $S e{ }^{N e u}$ and wild-type eight-cell stage embryos. The resulting Sey/Sey ${ }^{\mathrm{Neu} \leftrightarrow}+1+$ chimeric embryos provided an environment in which wild-type and Sey/Sey ${ }^{\mathrm{Neu}} \mathrm{mu}-$ tant cells could mix and interact. Each mutant cell carried a reiterated transgene to distinguish between mutant and wild-type cells. This provided a means of testing whether Sey/Sey ${ }^{\mathrm{Neu}}$ cells were rescued by surrounding wild-type cells in the affected tissues and, if so, whether the two types of cells mixed normally. Specifically, the failure of wild-type cells to rescue mutant cells in a tissue implies that $P a x 6$ gene expression is required in that tissue and acts cell autonomously. Although a system- 


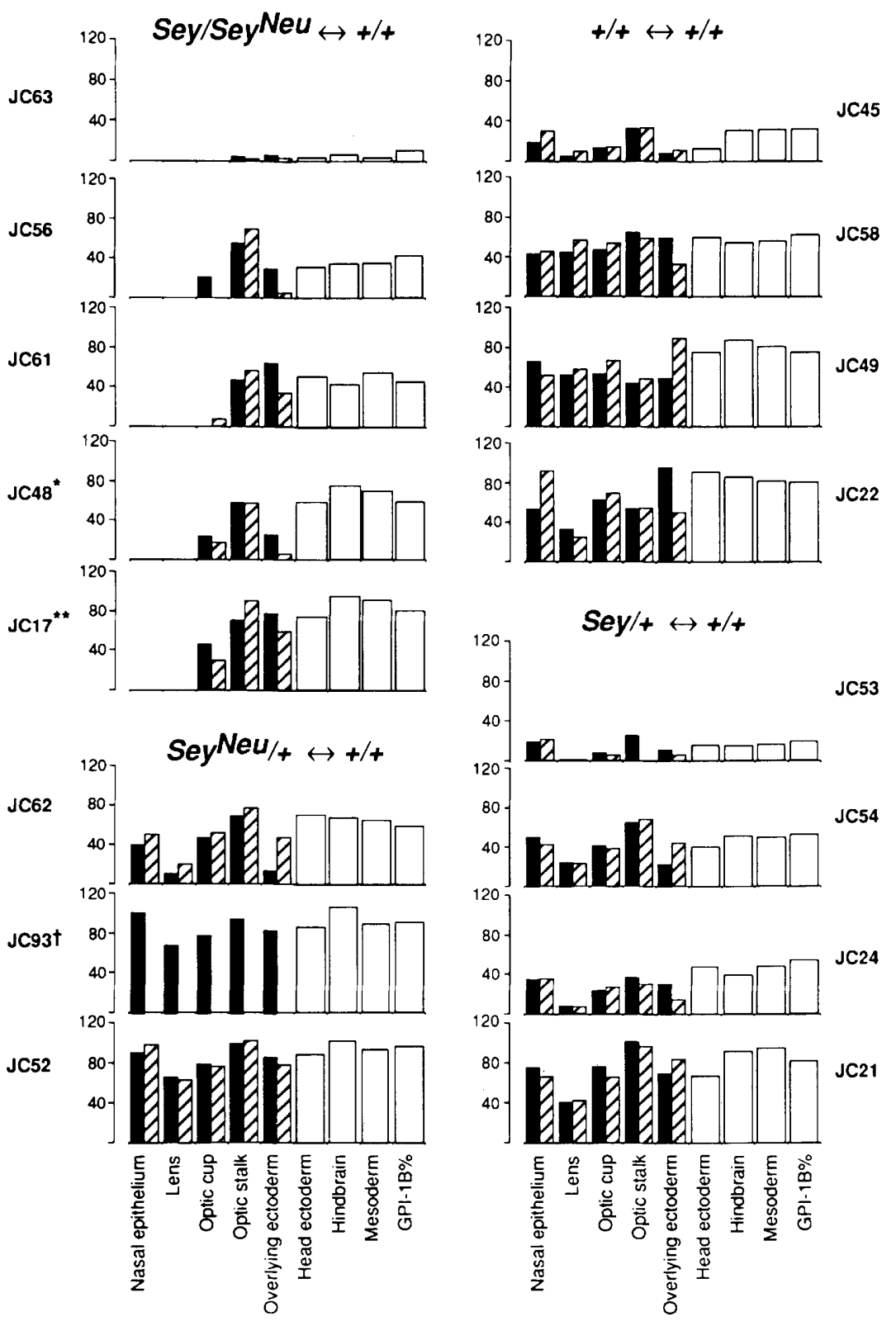

Figure 5. Histograms showing the contribution of $\left(\mathrm{Sey}^{\mathrm{Neu}} /+\times \mathrm{Sey} /+\mid\right.$ cells to different tissues of 16 chimeric fetuses of four different genotypes. The contribution to the fetal trunk is given as the mean \% GPIlB /calculated from separate estimates of \%GPIIB in the tail and one forelimb). The contributions to normal RPE (where present) was estimated as the percent pigmented RPE cells. The contributions to other tissues were estimated by the corrected hybridization index /see Materials and methods) from three widely separated histological sections. (Solid bar) left; (hatched bar) right; (open bar) unpaired tissues. For eye tissues, these were the midsection of the eye and the two sections that were halfway between the midsection and the first or last section, respectively. Results for the neural retinal and RPE are presented together as the optic cup because these tissues were morphologically abnormal in some $\mathrm{Sey}^{\mathrm{Neu}} / \mathrm{Sey} \leftrightarrow+1+$ chimeras. For the 11 control, Sey ${ }^{\mathrm{Neu}} /+\leftrightarrow+1+$, Sey $/+\leftrightarrow+/+$ and $+1+\leftrightarrow+1+$ chimeras, the mean \%GPIIB correlated well (Spearman's rank correlation coefficient, $r_{s}$ / with the hybridization index for all of the tissues analysed apart from the right optic stalk: left nasal epithelium $\mid r_{\mathrm{s}}=0.918$; $P=0.004)$; right nasal epithelium $\left(\mathrm{r}_{\mathrm{s}}=0.964\right.$; $P=0.004)$; left lens $\left(\mathrm{r}_{\mathrm{s}}=0.891 ; P=0.005\right)$; right lens $\left(r_{\mathrm{s}}=0.842 ; P=0.012\right)$; left neural retina $\left(\mathrm{r}_{\mathrm{s}}=0.945 ; \quad P=0.003\right)$; right neural retina $\left(\mathrm{r}_{\mathrm{s}}=0.927 ; \quad P=0.005\right) ; \quad$ left RPE $\left(\mathrm{r}_{\mathrm{s}}=0.964\right.$; $P=0.002)$; right $\mathrm{RPE}\left(\mathrm{r}_{\mathrm{s}}=0.976 ; P=0.003\right)$; left total optic cup $\left(r_{s}=0.982 ; P=0.002\right)$; right total optic cup $\left(\mathrm{r}_{\mathrm{s}}=0.952 ; P=0.004\right)_{;}$left optic stalk $\left.\mid \mathrm{r}_{\mathrm{s}}=0.788 ; \quad P=0.013\right) ; \quad$ right optic stalk $\left(\mathrm{r}_{\mathrm{s}}=0.600 ; P=0.090\right)$; ectoderm overlying left eye $\left(r_{\mathrm{s}}=0.900 ; P=0.004\right)$; ectoderm overlying right eye $\left(\mathrm{r}_{\mathrm{s}}=0.855 ; P=0.010\right)$; head ectoderm $\left(\mathrm{r}_{\mathrm{s}}=0.782 ; \quad P=0.013\right) ;$ hindbrain $\mid \mathrm{r}_{\mathrm{s}}=0.964$; $P=0.002)$; and mesoderm $\left(r_{s}=0.961 ; P=0.002\right)$. $\left({ }^{*}\right)$ Chimera JC48 had no lens in its left eye $\left.{ }_{i}{ }^{* *}\right)$ chimera JCl 7 had no lens in either eye; ${ }^{+}$tissues from the left side of the head were not analyzed from chimera IC93. atic analysis of cell mixing was not undertaken, the distribution of the transgenic and nontransgenic cells, in various embryonic tissues unaffected by the Sey mutation, was apparently similar in the $\mathrm{Sey} / \mathrm{Sey}^{\mathrm{Neu}} \leftrightarrow+/+$ and control chimeras. In contrast, the developing eyes and nasal epithelium showed abnormal participation of the Sey/Sey ${ }^{N e u}$ cells and highlighted similarities in the developmental requirements of the lens and nasal epithelium.

\section{Role of Pax6 in lens and nasal epithelium formation}

In the Sey/Sey ${ }^{\mathrm{Neu}} \leftrightarrow+/+$ chimeras, Sey/Sey ${ }^{\mathrm{Neu}}$ cells were not detected in the lens or nasal epithelium at E12.5. The inability to participate in the development of these epithelial tissues, populated by $+/+$ cells, shows that the Sey/Sey ${ }^{N e u}$ cells are incapable of rescue and that Pax6 activity is direct and cell autonomous. Thus, Pax6 has a cell-autonomous role at a stage of lens and nasal epithelia formation preceding E12.5. The lens and nasal epithelium are derived from the head ectoderm. Figure 5 shows that the proportion of Sey/Sey ${ }^{\mathrm{Neu}}$ cells in other regions of the head ectoderm was similar to that in the fetal trunk (\%GPI1B) and other tissues, in which Pax6 has no apparent influence. This proportion is probably representative of the chimera as a whole. Thus, initially, the regions of head ectoderm that form the lens and nasal placodes are likely to have been composed of a similar mixture of mutant and wild-type cells. Mutant cells would subsequently be lost from the lens and nasal lineages at the stage of earliest Pax6 function. Previous 
analysis of Sey/Sey homozygous mice showed not only that lens and nasal cavities fail to form but that at E9.5 there is no evidence for thickening of the surface ectoderm indicative of lens and nasal placode formation (Hogan et al. 1986; Grindley et al. 1995). Placode formation is the earliest morphological indicator of lens and nasal differentiation. It was suggested (Grindley et al. 1995) that in Sey/Sey homozygous mice the normal transition from head ectoderm to placode formation is interrupted. The observations in the Sey/Sey ${ }^{N e u} \leftrightarrow+/+$ chimeras argue that $P a \times 6$ has a direct role in this early developmental decision such that head ectodermal cells, deficient in Pax6, are unable to proceed to the initial stages of epithelial morphogenesis. Thus, Pax6 is a necessary component of the system that specifies the pattern of the head. However, because the fates of lens and nasal epithelial cells are ultimately different, additional, perhaps exogenous, signals (Jacobson and Slater 1988) are necessary to specify the identity of these cells as either lens or nasal epithelium.

In the Sey/Sey ${ }^{N e u} \leftrightarrow+1+$ chimeras, there were inverse relationships between the \%GPI1B (overall percentage of the Sey/Sey ${ }^{N e u}$ mutant cells) and the amount of both lens and nasal epithelia. In addition, the production of both of these structures is dependent on a threshold of normal cells, below which no epithelium is detectable at the embryonic stage examined (E12.5). These observations lead to two predictions. First, we predict that the size of the lens and nasal tissues is solely dependent on the number of cells that are competent to form these tissues; that is, the wild-type cells. We cannot rule out the possibilities that Sey/Sey ${ }^{\mathrm{Neu}}$ cells are active inhibitors of lens development or that the level of a concentration-dependent exogenous signal (from outside the lens) is reduced in Sey/Sey ${ }^{N e u} \leftrightarrow+1+$ chimeras. However, our results, combined with failure of nasal and lens placode formation in nonchimeric, homozygous Sey/Sey mutants suggest that the size of these epithelia-derived structures is determined by the number of wild-type cells that constitute the placodal domains. Thus, in the chimeras, the primordia forming these specialized epithelia are smaller than normal and there is no subsequent compensatory growth mechanism.

Second, we predict that the there is a critical proportion of wild-type cells in the lens and nasal primordia needed to initiate the development of these structures. This is reminiscent of an experimental phenomenon referred to as the community effect (Gurdon et al. 1993). Briefly, this suggests that in development, cells communicate with like neighbors and that a critical number of interacting cells is required to proceed to the next stage in development. Thus, in the Sey/Sey ${ }^{\mathrm{Neu}} \leftrightarrow+/+$ chimeras, the presence of a high percentage of Sey/Sey ${ }^{\mathrm{Neu}}$ cells interrupts the sparse population of wild-type cells and the critical number of interacting wild-type cells is not reached. However, the possibility also exists that lens or nasal epithelium development begins in these tissues as a mixture of mutant and wild-type cells but subsequently degenerates because of the burden of the abnormal Sey/Sey ${ }^{\mathrm{Neu}}$ cells.

\section{Role of Pax6 in optic cup development}

Optic vesicle-derived tissue developed in all Sey/ Sey ${ }^{\mathrm{Neu}} \leftrightarrow+1+$ chimeras examined, and no simple correlation was observed between size and \%GPI1B. In contrast, the \%GPI1B correlated with the degree of tissue abnormality in the optic cup. This we attribute, at least in part, to abnormally small or absent lenses. Lens tissue is important as a regulator of retinal growth and in the maintenance of retinal development (Saha et al. 1992). In either the absence of the lens resulting from lens ablation (Breitman et al. 1987; Kaur et al. 1989; Harrington et al. 1991) or the presence of an abnormally small lens as in the mutant aphakia (Zwaan and Webster 1985; R.E. Hill, unpubl.) convoluted overgrowth of retinal tissue occurs. However, neither of these situations show the degree of abnormality demonstrated in the Sey/ Sey ${ }^{N e u} \leftrightarrow+/+$ chimeric eyes that lack a lens. It is not clear whether the Sey/Sey ${ }^{N e u}$ cells in the optic cup increase the degree of abnormality in this tissue.

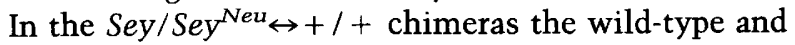
$\mathrm{Sey} / \mathrm{Sey}{ }^{\mathrm{Neu}}$ cells did not mix freely, resulting in large partitions consisting predominantly, if not exclusively, of either wild-type or mutant cells. Sharp boundaries with no detectable intermingling occurred between the cell types. In the lensless eyes the ocular tissue was highly convoluted and normal inner and outer layers were not identifiable. In these eyes the partitioning of the two cell types suggests a mechanism, operating at an earlier developmental stage, which sorts the cells into large patches of like cells. This failure of cell types to mix illustrates that differences exist between the wildtype and Sey/Sey ${ }^{\mathrm{Neu}}$ cells consistent with differences in cellular properties that define identity. It is likely that these differences lie at the cell surface.

It has been suggested that homeo domain-containing proteins control the expression of genes encoding extracellular matrix proteins and cell adhesion molecules (Edelman and Jones 1992; Jones et al. 1993; Goomer et al. 1994; Holst et al. 1994). Furthermore, Pax6 and other members of the Pax gene family are known to interact with the promoters of cell surface molecules and, in particular, those that belong to the immunoglobulin superfamily. For example, the evidence is strong that Pax 5 regulates the B-lymphocyte receptor CD19 (Kozmik et al. 1992), and Pax6 interacts with the neural cell adhesion molecule L1 promoter region in in vitro DNA-binding assays (Chalepakis et al. 1994). Thus, Pax6 deficiency may influence the expression of adhesion molecules or other cell surface molecules to effect the cell sorting.

In the eyes of Sey/Sey ${ }^{N e u} \leftrightarrow+/+$ chimeras, the optic cup appears more normal in the presence of a lens than in those where the lens is absent. In addition, there appears to be a relationship between the size of the lens (and therefore the overall contribution of Sey/Sey ${ }^{\mathrm{Neu}}$ cells; \% GPIIB / and the degree of tissue abnormalities. In the eyes with lenses the mutant cells were excluded more rigorously from the inner layer of the optic cup than from the outer layer. In all but one case (Fig. 3C), no appreciable patches of Sey/Sey ${ }^{\mathrm{Neu}}$ cells were detected in 
the inner layer. Most Sey/Sey ${ }^{N e u}$ cells in these optic cups were in the outer layers, either in abnormally thickened or ectopic tissue. In no cases examined were these cells found in the single cell layer of RPE. In the embryos with low \%GPIlB and larger lenses, the degree of tissue abnormalities was reduced, coincident with more extreme reduction of mutant cells in the optic cup. We suggest that the presence of a lens provides an environment in which the developmental conditions for the optic cup are more stringent. Therefore, the optic cup develops more normally and the mutant cells make only a very low overall contribution. The evidence that Sey/ $\mathrm{Sey}^{\mathrm{Neu}}$ cells were excluded from the RPE and apparently at a selective disadvantage in other regions of the optic cup, as well as being distributed nonrandomly, implies that Pax6 has a direct, cell-autonomous effect on the optic cup as well as the lens and nasal epithelium.

These chimeras provide evidence that Pax6 has a role in all the primary tissues of the eye, including the inner and outer layers of the optic cup. Pax6 exerts an effect prior to E12.5 at a time when overt differentiation is still undetectable in the inner layer. Because the fates of cells in the inner and outer layers differ and the optic cup is of different embryological origin than the lens and nasal epithelium, we suggest that Pax6 has multiple roles in eye and nasal development.

\section{Evolution of the role of Pax6}

Pax6 is highly conserved in evolution, and homologs have been found in Drosophila and Caenorhabditis elegans. Quite surprisingly, Drosophila Pax6 is also involved in eye development being responsible for the eyeless phenotype (Quiring et al. 1994; Halder et al. 1995). The similarity of the phenotype led to the suggestion that Pax6 may have a homologous role in the development of these highly divergent eye structures separated by extreme evolutionary distances. In C. elegans Pax6 has a role in patterning the head region (Chisholm and Horvitz 1995; Zhang and Emmons 1995). Thus, in vertebrates the roles of Pax6 in head ectoderm and in the eye may have descended from very ancient conserved functions.

A problem with generalization of conserved function based on phenotype alone is the possible fortuity of the observations (Hill and Davidson 1994). Pax6 is expressed in multiple domains of the head and brain in both mouse and Drosophila. Thus, a role for Pax6 may incidentally overlap in the eye. In addition, eye structure and development differ dramatically between the two species. Thus, similar phenotypic characteristics observed in Pax6 mutants in the two species may well be attributable to unrelated developmental defects. However, analysis of the Sey/Sey ${ }^{N e u} \leftrightarrow+/+$ chimeric mice provides evidence that Pax6 has an early role in neural retina development, prior to the appearance of differentiating retinal cells. In comparison, the Drosophila eyeless mutant shows that Pax6 also functions in retinal development and development is defective in the mutant at a stage prior to differentiation (Quiring et al. 1994). This provides further evidence that the Pax 6 homologs have equivalent functions in development, strengthening the argument for conserved developmental roles.

\section{Materials and methods}

\section{Mice}

Inbred BALB/c/Eumm mice were purchased from the Department of Medical Microbiology, University of Edinburgh. The founder stock of Sey ${ }^{\mathrm{Neu}} /+$ mice was kindly supplied by Dr. Jack Favor, Institüt für Genetik, Neuherberg, Germany. Sey ${ }^{\mathrm{Neu}}$ arose on a $(\mathrm{C} 3 \mathrm{H} \times 102) \mathrm{F}_{1}$ genetic background and was crossed to a CBA/Ca genetic background. The Sey allele (Roberts 1967) was maintained on a partially congenic CBA/Ca-Sey/+ stock. Other stocks were produced and maintained in the Centre for Reproductive Biology (Edinburgh). Transgenic strain 83 (Lo $1986)$ carries the reiterated $\beta$-globin, $\operatorname{TgN}(\mathrm{Hbb}-\mathrm{bl}) 83 \mathrm{Clo}$ transgene (abbreviated to $\mathrm{Tg}$ ) and was used to derive the randombred, homozygous $\mathrm{Tg} / \mathrm{Tg}$ stock TGB on a largely (C57BL/ Ola $\times$ CBA/Ca) genetic background (Keighren and West 1994; West et al. 1995). A Sey/ + stock (SEYTG), which was homozygous for the transgene $(T g / T g)$, was produced by intercrossing $\mathrm{CBA} / \mathrm{Ca}-\mathrm{Sey} /+$ and TGB and backcrossing Sey/ + individuals to $\mathrm{TGB}$; Sey/,$+ \mathrm{Tg} / \mathrm{Tg}$ mice were used in the experiment after two to four backcross generations. The albino, Gpi1 $/ G_{p i 1}^{c}$, $\mathrm{CF}_{1}$ hybrid stock was produced from crosses between C57BLGpi1 ${ }^{c}, c /$ Ws females and BALB/c-Gpi1 ${ }^{c} /$ Ws males (West and Flockhart 1994).

\section{Production and dissection of chimeras}

Eight-cell embryos were obtained from two crosses. CBA/Ca$\mathrm{Sey}^{\mathrm{Neu}} /+$ females were mated to SEYTG $(\mathrm{Sey} /+, \mathrm{Tg} / \mathrm{Tg})$ males to produce a mixture of Sey ${ }^{\mathrm{Neu}} / \mathrm{Sey}, \mathrm{Sey} y^{\mathrm{Neu}} /+,+/ \mathrm{Sey}$, and $+/+$ embryos, all of which were $G p i 1^{b}, C / G p i 1^{b}, C-/ T g$. Inbred BALB/c mice were intercrossed to produce wild-type, albino embryos $\left(G p i 1^{a}, c / G p i 1^{a}, c\right)$ without the transgene. Chimeras were made by aggregating embryos from the two crosses and the four groups of chimeras $/ \mathrm{Sey}^{\mathrm{Neu}} / \mathrm{Sey} \leftrightarrow+/+, \mathrm{Sey}^{\mathrm{Neu}} /+\leftrightarrow+1$ + , Sey $/+\leftrightarrow+/+$, and $+/+\leftrightarrow+/+$ ) were distinguished retrospectively by PCR analysis as described below.

$\mathrm{BALB} / \mathrm{c}$ and $\mathrm{CBA} / \mathrm{Ca}-\mathrm{Sey}^{\mathrm{Neu}} /+$ females were induced to ovulate by intraperitoneal (i.p) injection of $5 \mathrm{KU}$ of pregnant mares' serum gonadotrophin (PMSG) at $\sim 12$ noon, followed 48 hr later by i.p. injection of 5 IU of human chorionic gonadotrophin (hCG). Females were caged overnight with males of the appropriate stock, and mating was confirmed the following morning by the presence of a vaginal copulation plug; the day of the vaginal plug was designated 0.5 day postcoitum (d.p.c.). On the same day as vaginal plugs were identified, $\mathrm{CF}_{1}$ females in estrus were paired overnight with vasectomized $\mathrm{CF}_{1}$ males and mating was verified the following morning by the presence of a vaginal plug. These provided homozygous, Gpi1 $/ 1^{c} p i 1^{c}$ pseudopregnant females for embryo recipients.

Embryos were flushed from the CBA/Ca-Sey $\mathrm{Neu} /+$ and $\mathrm{BALB} / \mathrm{c}$ females at 2.5 d.p.c. with HEPES-buffered $\mathrm{M} 2$ handling medium (Quinn et al. 1982). Aggregations were carried out according to methods used by West and Flockhart (1994). After overnight culture, the aggregated embryos were surgically transferred to the uteri of pseudopregnant $\mathrm{CF}_{1}$ females. Pregnancies were timed according to the pseudopregnant female, with the plug day being 0.5 d.p.c; the recipient female was sacrificed at 12.5 d.p.c (E12.5). This age was chosen because normal $\mathrm{RPE}$ pigmentation is well established and provides a marker for the chimera analysis (see below). 
Fetuses were dissected into cold PBS. The weight of the total conceptus, fetus, and placenta were recorded along with the crown-rump length and morphological index based on hindlimb development (McLaren and Buehr 1990; Palmer and Burgoyne 1991). Different samples of the conceptus were analyzed by GPI electrophoresis, PCR, and in situ hybridization to the reiterated transgene (Fig. 1). Tissue samples dissected for GPI1 electrophoresis into $\mathrm{H}_{2} \mathrm{O}$ /glycerol 50:50 from the tail, forelimb, amnion, whole yolk sac, and placenta. Methods used for GPI1 electrophoresis as described in West and Flockhart (1994). The trunk was digested for $24 \mathrm{hr}$ at $55^{\circ} \mathrm{C}$ in $0.5 \mathrm{ml}$ of proteinase $\mathrm{K}$ buffer $\left(5 \mathrm{~mm}\right.$ Tris, $25 \mathrm{~mm} \mathrm{KCl}, 25 \mathrm{~mm} \mathrm{MgCl}_{2}$ at $\mathrm{pH} 7.8,0.45 \%$ NP-40, $0.45 \%$ Tween, $0.1 \mathrm{mg} / \mathrm{ml}$ of gelatin) plus $300 \mu \mathrm{g}$ of proteinase $\mathrm{K}$. The head of each fetus was fixed in ethanol/acetic acid $[3: 1(\mathrm{vol} / \mathrm{vol})]$ and then processed to wax for analysis by DNA-DNA in situ hybridization.

\section{Analysis of genomic DNA}

The four groups of chimeras $\left(\mathrm{Sey}^{\mathrm{Neu}} / \mathrm{Sey} \leftrightarrow+1+\right.$, Sey ${ }^{\mathrm{Neu}} /$ $+\leftrightarrow+/+$, Sey $/+\leftrightarrow+1+$, and $+/+\leftrightarrow+/+1$ were distinguished by PCR analysis of Pax 6 genes in samples of fetal trunk DNA. After digestion in proteinase $\mathrm{K}$ buffer (see above), the resulting suspension was denatured at $95^{\circ} \mathrm{C}$ for $5 \mathrm{~min}$. One microliter was then added to a PCR mixture containing $50 \mathrm{~mm}$ $\mathrm{KCl}, 10 \mathrm{~mm}$ Tris- $\mathrm{HCl}$ (pH 8.3), $1.5 \mathrm{~mm} \mathrm{MgCl}_{2}, 0.1 \%$ Triton $\mathrm{X}-100,0.1 \mathrm{~mm}$ of each dNTP, and 1.5 units of Taq DNA polymerase (Boehringer Mannheim) per 50- $\mu$ l volume. Primers Hax-5 (ATGGAACCTGATGTGAAGGAGG) and G15 (GCAACACTCCTAGTCACATTCC) or MC130 (CTTTCTCCAGGGCCTCAATCTG) and G459 (GCAACAGGAAGGAGGGGGAGA) were used to amplify 220- and 148-bp fragments, respectively, from within the Pax6 gene for identification of the $\mathrm{Sey}{ }^{\mathrm{Neu}}$ and Sey mutations. For the analysis of the Sey ${ }^{\mathrm{Neu}}$ mutation, $20 \mu \mathrm{l}$ of PCR product was digested with 9 units of HindII, and for the Sey mutation $30 \mu \mathrm{l}$ of PCR product was digested with 30 units of DdeI (as per manufacturer's instructions; Boehringer Mannheim|. Samples were loaded onto a $15 \%$ polyacrylamide gel $(19: 1$, acrylamide/bis-acrylamide $\}$ and subjected to electrophoresis in TBE buffer at $280 \mathrm{~V}$ for $2 \mathrm{hr}$. Restriction fragments were fixed in the gel by washing twice in $10 \%$ ethanol, $0.5 \%$ acetic acid, before incubation for $10 \mathrm{~min}$ in $6 \mathrm{mM} \mathrm{AgNO}_{3}$. Gels were washed twice in distilled water and then stained for $20 \mathrm{~min}$ in $375 \mathrm{mM} \mathrm{NaOH}, 3 \mathrm{mM} \mathrm{NaBH}_{4}$ and $0.16 \%$ formaldehyde to visualize fragments (C.M. Abbott, unpub.). After transfer to distilled water, the gels were photographed.

To verify the genotype of chimeras where mutant sequences were present in low proportion, a second "nested" PCR reaction was carried out to reduce possible low-level nonspecific sequence amplification. The PCR mixture and enzyme concentrations were as before. First round primers for Sey fragments were B509/3 (TGCCAGCAACAGGAAGGAGG) and F769 (GGGCAAAGACATCTGGATAATG), and for Sey ${ }^{\mathrm{Neu}}$ were Hax -5 (see above) and 7772 (CATTATCCAGATGTGTTTGCCC). These were subjected to 15 cycles at $95^{\circ} \mathrm{C}$ for $0.5 \mathrm{~min}$, $56^{\circ} \mathrm{C}$ for $0.75 \mathrm{~min}$, and $72^{\circ} \mathrm{C}$ for $1.0 \mathrm{~min}$. One microliter of the resultant PCR mixure was transferred to a new tube containing either second-round Sey primers MC130 and G459 or Sey ${ }^{\mathrm{Neu}}$ primers $\mathrm{Hax}_{-5}$ and G15. This mixture was then subjected to a further 30 cycles at $95^{\circ} \mathrm{C}$, for $0.5 \mathrm{~min}, 55^{\circ} \mathrm{C}$ for $0.75 \mathrm{~min}$, and $72^{\circ} \mathrm{C}$ for $1.0 \mathrm{~min}$. Nested PCR products were of identical size to original PCR assay, with Sey being 148 bp and Sey ${ }^{\mathrm{Neu}}$ being 220 bp. Fragments were digested and subjected to polyacrylamide gel electrophoresis and silver staining as described above. Original genotype results for chimeras where the proportion of mutant sequence was very low le.g., chimera JC63 where $\sim 5 \%$ of genomic DNA contained the Sey or Sey ${ }^{\mathrm{Neu}}$ sequence/ were duplicated using the nested PCR procedure and thus specificity and sensitivity of the original genotyping procedure confirmed.

\section{DNA-DNA In Situ Hybridization}

Sections were cut at $7 \mu \mathrm{m}$ and mounted on slides coated with 3-aminopropyltriethoxysilane (Sigma) and analyzed by in situ hybridization to the transgene as described by Keighren and West (1993). Hybridized digoxygenin-labeled DNA probe was detected by diaminobenzidine (DAB) staining for peroxidaselabeled antibody (nonradioactive DNA labeling and detection kit; Boehringer Mannheim). Slides were counter stained with hematoxylin and eosin and examined by bright-field and phasecontrast light microscopy.

\section{Analysis of E12.5 chimeras}

The \%GPIIB contribution was estimated by scanning densitometry of GPI electrophoresis plates (West and Flockhart 1994). The average \%GPIIB in the fetal tail and forelimb was used as an estimate of the overall contribution of $\left[\mathrm{Sey}^{\mathrm{Neu}}\right.$ / $+\times$ Sey $/+1$ cells to the fetus.

After DNA in situ hybridization, the percentage of transgenepositive cells in each of the selected test tissues was estimated (James et al. 1995) in each of the fetuses examined by phasecontrast light microscopy. The contribution of transgenic $(\mathrm{Tg} /$ - ) cells was estimated for each tissue in three widely spaced sections. For tissues in the eye, the midsection and the two sections that were halfway from the mid- to the first or last section were selected for examination. An eyepiece grid and a standardized sampling protocol was used for each separate tissue, and $\sim 150-1000$ cells were classified, depending on the tissue. For some tissues, for example, where cells were densely packed, individual cells were not classified but the total number of cells and the total number of hybridization signals were counted in the same field of view. For morphologically normal RPE, $\left(\mathrm{Sey}^{\mathrm{Neu}} /+\times \mathrm{Sey} /+\right)$ cells were identified as pigmented and/or positive for the hybridization signal.

The primary estimates of percent hybridization-positive cells were corrected to allow for the failure to detect a hybridization signal in a proportion of the $\mathrm{Tg} /-\left(\mathrm{Sey}^{\mathrm{Neu}} /+\times\right.$ Sey $/+\mid$ cells. The tissue-specific correction factors were derived from the following estimates of percent hybridization for tissues from two hemizygous transgenic ( $\mathrm{Tg} /-\mid \mathrm{E} 12.5$ fetuses: nasal epithelium, $105.5 \%$; lens, $83.3 \%$; optic cup, $84.5 \%$; overlying ectoderm (overlying the eye), $64.5 \%$; head ectoderm, $56.8 \%$; hindbrain, $89.1 \%$; head mesoderm, $88.5 \%$. Most of these estimates are below $100 \%$, because in histological sections, a proportion of nuclei fail to include a hybridization signal. In densely packed tissues, the number of hybridization signals may be greater than the number of identifiable nuclei in the field of view, because of overlapping nuclei (e.g., nasal epithelium estimate of $105.5 \%$ ). The final corrected hybridization index may also exceed $100 \%$ if the contribution of $\mathrm{Tg} /$ - cells in the chimaera is close to $100 \%$ and the correction factor overcompensates.

\section{Estimation of lens and nasal epithelium size}

The area of the lens or nasal epithelium in one histological section (where the area was maximum) was used as a measure of tissue size. Areas were estimated (Curtis 1960) using a modified Chalkley grid (Graticules Ltd., Tonbridge Kent, UK). 


\section{Statistical analysis}

Statistical tests were performed on an Apple Macintosh computer using the statistical package StatView 4.1 (Abacus Concepts Inc., Berkeley, CA).

\section{Acknowledgments}

We thank Margaret Keighren, Jean Flockhart, Denis Doogan, Maureen Ross, and Jim Macdonald /Centre for Reproductive Biology), Vince Rinaldi and the staff of the Biomedical Research Facility (Western General Hospital) for expert technical assistance, and Norman Davidson, Tom McFetters, and Ted Pinner for assistance in preparing the illustrations. We also thank Jack Favor for kindly providing the Sey ${ }^{N e u}$ founder stock, and Nick Hastie, Duncan Davidson, Penny Rashbass, and Clare Everett for helpful comments on the manuscript. Figure 1 is based on an original diagram by Clare Everett. J.C.Q. is grateful to the Faculty of Medicine, University of Edinburgh, for a Ph.D. studentship, and J.D.W. is grateful to the Wellcome Trust for financial support (grant 036737 ).

The publication costs of this article were defrayed in part by payment of page charges. This article must therefore be hereby marked "advertisement" in accordance with 18 USC section 1734 solely to indicate this fact.

\section{References}

Breitman, M.L., S. Clapoff, J. Rossant, L.-C. Tsui, M. Glode, I.H. Maxwell, and A. Bernstein. 1987. Genetic ablation: Targeted expression of a toxin gene causes microphthalmia in transgenic mice. Science 238: 1563-1565.

Chalepakis, G., J. Wijnholds, P. Giese, M. Schachner, and P. Gruss. 1994. Characterization of Pax- 6 and Hox-1 binding to the promoter region of the neural cell-adhesion molecule L1. DNA Cell Biol. 13: 891-900.

Chisholm, A. D. and H.R. Horvitz. 1995. Patterning of the Caenorhabditis elegans head region by the Pax- 6 family member vab-3. Nature 377: 52-55.

Coulombre, A.J. 1965. Experimental embryology of the vertebrate eye. Invest. Ophthalmol. 4: 411-419.

Curtis, A.S.G. 1960. Area and volume measurements by random sampling methods. Med. Biol. Illust. 10: 261-266.

Edelman, G.M. and F.S. Jones. 1992. Cytotactin-A morphoregulatory molecule and a target for regulation by homeobox gene-products. Trends Biochem. Sci. 17: 228-232.

Everett, C.A. and J.D. West. 1996. The influence of ploidy on the distribution of cells in chimaeric mouse blastocysts. Zygote (in press).

Fujiwara, M., T. Uchida, N. Osumi-Yamashita, and K. Eto. 1994. Uchida rat (rSey): A new mutant with craniofacial abnormalities resembling those of the mouse Sey mutant. Differentiation 57: 31-38.

Glaser, T., L. Jepeal, J.G. Edwards, S.R. Young, J. Favor, and R. Maas. 1994. PAX6 gene dosage effects in a family with congenital cataracts, aniridia, anophthalmia and central nervous system defects. Nature Genet. 7: 463-471.

Goomer, R.S., B.D. Holst, I.C. Wood, G.M. Edelman, and F.S. Jones. 1994. Regulation in-vitro of an L-cam enhancer by homeobox genes Hoxd9 and HNF-1. Proc. Natl. Acad. Sci. 91: $7985-7989$.

Grainger, R.M. 1992. Embryonic lens induction: Shedding new light on vertebrate tissue determination. Trends Genet. 8: 349-355.

Grindley, J.C., D.R. Davidson, and R.E. Hill. 1995. The role of Pax-6 in eye and nasal development. Development 121: 1433-1442.
Gurdon, J.B., P. Lemaire, and K. Kato. 1993. Community effects and related phenomena in development. Cell 75: 831-834.

Halder, G., P. Callaerts, and W.J. Gehring. 1995. Induction of ectopic eyes by targeted expression of the eyeless gene in Drosophila. Science 267: 1788-1792.

Hanson, I.M., A. Seawright, K. Hardman, S. Hodgson, D. Zaletayev, G. Fekete, and V. van Heyningen. 1993. PAX6 mutations in aniridia. Hum. Molec. Genet. 2: 915-920.

Hanson, I.M., J.M. Fletcher, T. Jordan, A. Brown, D. Taylor, R.J. Adams, H. Punnett, and V. van Heyningen. 1994. Mutations at the PAX6 locus are found in heterogeneous anterior segment malformations including Peter's anomaly. Nature Genet. 6: 168-173.

Harrington, L., G.K. Klintworth, T.E. Secor, and M.L. Breitman. 1991. Developmental analysis of ocular morphogenesis in $\alpha \mathrm{A}$-crystallin/diptheria toxin transgenic mice undergoing ablation of the lens. Dev. Biol. 148: 508-516.

Hill, R.E. and D.R. Davidson. 1994. Comparative development, seeing eye to eye. Curr. Biol. 4: 1155-1157.

Hill, R.E., J. Favor, B.L.M. Hogan, C.C.T. Ton, G.F. Saunders, I.M. Hanson, J. Prosser, T. Jordan, N.D. Hastie, and V. van Heyningen. 1991. Mouse Small eye results from mutations in a paired-like homeobox-containing gene. Nature 354: 522-525.

Hogan, B.M., G. Horsburgh, J. Cohen, C.M. Hetherington, G. Fisher, and M.F. Lyon. 1986. Small eyes (Sey): A homozygous lethal mutation on chromosome 2 which affects the differentiation of both lens and nasal placodes in the mouse. J. Embryol. Exp. Morphol. 97: 95-110.

Hogan, B.L.M., E.M.A. Hirst, G. Horsburgh, and C.M. Hetherington. 1988. Small eye (Sey): A mouse model for the genetic analysis of craniofacial abnormalities. Development (Suppl.) 103: 115-119.

Holst, B.D., R.S. Goomer, I.C. Wood, G.M. Edelman, and F.S. Jones. 1994. Binding and activation of the promoter for the neural cell-adhesion molecule by Pax-8. 1 . Biol. Chem. 269: 22245-22252.

Jacobson, A.G. and A.K. Slater. 1988. Features of embryonic induction. Development 104: 341-359.

James, R.M., A.H.E.M. Klerkx, M. Keighren, J.H. Flockhart, and J.D. West. 1995. Restricted distribution of tetraploid cells in mouse tetraploid $\leftrightarrow$ diploid chimaeras. Dev. Biol. 167: 213226.

Jones, F.S., B.D. Holst, O. Minowa, E.M. DeRobertis, and G.M. Edelman. 1993. Binding and transcriptional activation of the promoter for the neural cell-adhesion molecule by Hoxc6 (Hox-3.3). Proc. Nat1. Acad. Sci. 90: 6557-6561.

Jordan, T., I. Hanson, D. Zaletayev, S. Hodgson, J. Prosser, A. Seawright, N. Hastie, and V. van Heyningen. 1992. The human PAX6 gene is mutated in two patients with aniridia. Nature Genet. 1: 328-332.

Kaur, S., B. Key, J. Stock, J.D. McNeish, R. Akeson, and S.S. Potter. 1989. Targeted ablation of alpha-crystallin-synthesizing cells produces lens-deficient eyes in transgenic mice. Development 105: 613-619.

Keighren, M. and J.D. West. 1993. Analysis of cell ploidy in histological sections of mouse tissues by DNA-DNA in situ hybridization with digoxygenin labelled probes. Histochem. I. 25: 30-44.

1994. Two new partially congenic transgenic strains. Mouse Genome 92: 666.

Kozmik, Z., S. Wang, P. Dorfler, B. Adams, and M. Busslinger. 1992. The promoter of the CD19 gene is a target for the B-cell-specific transcription factor BSAP. Mol. Cell. Biol. 12: 2662-2672.

Li, H.-S., J.-M. Yang, R.D. Jacobson, D. Pasko, and O. Sundin. 


\section{Quinn et al.}

1994. Pax-6 is first expressed in a region of ectoderm anterior to the early neural plate: implications for stepwise determination in the lens. Dev. Biol. 162: 181-194.

Lo, C. 1986. Localization of low abundance DNA sequences in tissue sections by in situ hybridization. J. Cell Sci. 81: 143162.

Lo, C.W., M. Coulling, and C. Kirby. 1987. Tracking of mouse cell lineage using microinjected DNA sequences: Analysis using genomic Southern blotting and tissue-section in situ hybridizations. Differentiation 35: 37-44.

Matsuo, T., N. Osumi-Yamashita, S. Noii, H. Ohuchi, E. Koyama, F. Myokai, N. Matsuo, S. Taniguchi, H. Doi, S. Iseki, Y. Ninomiya, M. Fujiwara, T. Watanabe, and K. Eto. 1993. A mutation in the Pax-6 gene in rat small eye is associated with impaired migration of midbrain crest cells. $\mathrm{Na}$ ture Genet. 3: 299-304.

McLaren, A. and M. Buehr. 1990. Development of mouse germ cells in cultures of fetal gonads. Cell Differ. Dev. 31: 185195.

Palmer, S.J. and P.S. Burgoyne. 1991. The Mus musculus do mesticus Tdy allele acts later than the Mus musculus musculus Tdy allele: A basis for $\mathrm{XY}$ sex reversal in C57BL/6$\mathrm{Y}^{\mathrm{POS}}$ mice. Development 113: 709-714.

Quinn, P., C. Barros, and D.G. Whittingham. 1982. Preservation of hamster oocytes to assay the fertilizing capacity of human spermatozoa. J. Repr. Fertil. 66: 161-168.

Quiring, R., U. Walldorf, U. Kloter, and W. Gehring. 1994. Homology of the eyeless gene of Drosophila to the Small eye gene in mice and Aniridia in humans. Science 265: 785-789.

Roberts, R.C. 1967. Small eyes-A new dominant eye mutant in the mouse. Genet. Res. 9: 121-122.

Saha, M.S., M. Servetnick, and R.M. Grainger. 1992. Vertebrate eye development. Curr. Opin. Genet. Dev. 2: 582-588.

Saha, M.S., C.L. Spann, and R.M. Grainger. 1989. Embryonic lens induction: More than meets the optic vesicle. Cell Differ. Dev. 28: 153-172.

Schmahl, W., M. Knoedlseder, J. Favor, and D. Davidson. 1993. Defects in neuronal migration and the pathogenesis of cortical malformations are associated with Small eye (Sey) in the mouse, a point mutation of the Pax-6-locus. Acta Neuropathol. 86: 126-135.

Smelser, G.K. 1965. Embryology and morphology of the lens. Invest. Ophthalmol. 4: 398-410.

Stuart, E.T., C. Kioussi, and P. Gruss. 1994. Mammalian Pax genes. Annu. Rev. Genet. 28: 219-236.

Ton, C.C.T., H. Hirovenen, H. Miwa, M.W. Weil, A.P. Monaghan, T. Jordan, V. van Heyningen, N.D. Hastie, H. Meijers-Heijboer, M. Dreschler, B. Royer-Pokora, F. Collins, A. Swaroop, L.C. Strong, and G.F. Saunders. 1991. Positional cloning and characterization of a paired box and homeobox containing gene from the aniridia region. Cell 67: 10591074.

Walther, C. and P. Gruss. 1991. Pax-6, a murine paired box gene, is expressed in the developing CNS. Development 113: 1435-1449.

West, J.D., C.A. Everett, and M. Keighren. 1995. Corrections to transgenic nomenclature. Mouse Genome 93: 145.

West, J.D. and J.H. Flockhart. 1994. Genotypically unbalanced diploid $\leftrightarrow$ diploid foetal mouse chimaeras: Possible relevance to human confined mosaicism. Genet. Res. 63: 87-99.

Zhang, Y.H. and S.W. Emmons. 1995. Specification of senseorgan identity by a Caenorhabditis elegans Pax -6 homolog. Nature 377: 55-59.

Zwaan, J. and E.H. Webster. 1985. Localisation of keratin in the cells of the cornea in aphakia and normal mouse. Exp. Eye Res. 40: 127-133. 


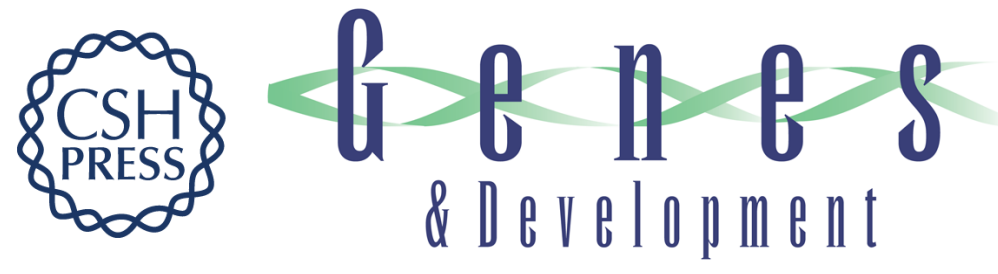

\section{Multiple functions for Pax6 in mouse eye and nasal development.}

J C Quinn, J D West and R E Hill

Genes Dev. 1996, 10:

Access the most recent version at doi:10.1101/gad.10.4.435 $\begin{array}{ll}\text { References } & \begin{array}{l}\text { This article cites } 49 \text { articles, } 16 \text { of which can be accessed free at: } \\ \text { http://genesdev.cshlp.org/content/10/4/435.full.html\#ref-list-1 }\end{array}\end{array}$

License

Email Alerting

Receive free email alerts when new articles cite this article - sign up in the box at the top Service right corner of the article or click here.

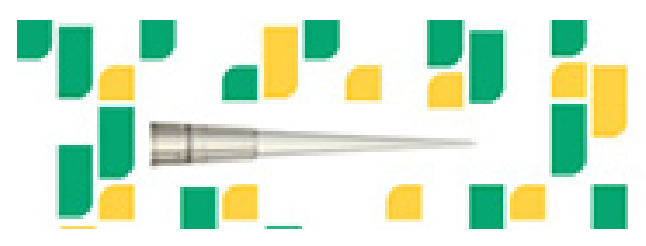

Focused on your science.

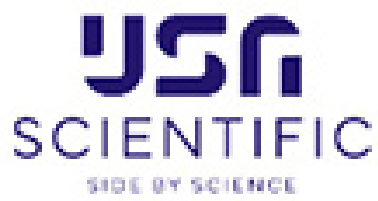

Copyright (c) Cold Spring Harbor Laboratory Press 